Acta Univ. Sapientiae, European and Regional Studies, 9 (2016) 5-6

DOI: $10.1515 /$ auseur-2016-0001

\title{
Linguistic Justice Scrutinized
}

\author{
Philippe VAN PARIJS \\ Université de Louvain \\ Chaire Hoover d'éthique économique et sociale \\ Philippe.vanParijs@uclouvain.be
}

We humans are linguistic beings. We are endowed with the ability to speak and to understand what others say. It is to this ability that we owe our potential for civilization, for behaving with each other in a civilized, fair way. Or, at least, it is to this ability that we owe the reasonable hope that we possess such a potential. However, once there is more than one language, more than one code for facilitating communication, and once people mastering distinct languages interact with one another on a regular basis, a language is not only a medium for sharing information, instructions, and reasons. It is also a means of exclusion, hierarchy, domination, and unfairness.

In today's world, interaction between people who do not possess the same native language has reached an unprecedented level. This fact I regard not only as irreversible but also as bound to further gain in importance in the coming decennia. At the same time, and largely for related reasons, human populations are becoming increasingly interdependent - throughout the world and more intensively within Europe. They are, therefore, in ever greater need of finding civilized ways of sharing a continent and a planet. And this requires being able to talk and listen more intensively, more effectively, and more cheaply than ever before.

For reasons spelt out at the onset of my Linguistic Justice, there is no promising way of achieving this except through the democratization of competence in one natural language, and this language will be something that can be called 'English'. ${ }^{1}$ Since this indispensable lingua franca is very unequally close to the native languages of European citizens and of human beings generally, its dominance creates sizeable inequalities that can legitimately be regarded as unjust. The bulk of Linguistic Justice consists in discussing them in a systematic way and in proposing strategies for neutralizing or alleviating them.

1 See Chapter 1 of P. Van Parijs, Linguistic Justice for Europe and for the World, Oxford: Oxford University Press, 2011; paperback 2015; German edition: Sprachengerechtigkeit für Europa und die Welt, Berlin: Suhrkamp, 2013; Dutch edition: Taal en rechtvaardigheid in Europa en de wereld, Leuven: Lannoo Campus, 2015. 
The set of insightful essays collected in the present volume stems from a particularly intense and stimulating international workshop that took place at the University of Amsterdam in November 2015. They question either my assumptions or my conclusions or both in ways that force me to think harder on some of the issues I discussed in Linguistic Justice, often by convincingly highlighting the need for further empirical research.

In particular, the essays argue that I dismiss too lightly artificial languages as an alternative to English as lingua franca (Gobbo, Maat), that I misconstrue the maxi-min dynamics (Kruse), that I fail to address the question of the democratic legitimacy (as opposed to the usefulness for democracy) of the language regime I propose (Garcia), that I am assuming too easily that the latter will have a positive effect on the viability of a strongly 'social' Europe (Marácz), that I do not pay enough attention to the impoverishment of inter-cultural communication induced by the convergence on English (Wickström) or to the loss of cultural diversity induced by universal exposure to the Anglo-American culture (Morales-Gálvez), that I underestimate the possibility that the attempt to democratize the lingua franca might widen rather than narrow the gap between the better-off and the worse-off (Iannàccaro and Dell'Aquila), that I overlook the potential English may have for inter-communication in linguistically divided countries (Csata), that I fail to document sufficiently the brain drain effect of implementing the territorial protection of weaker languages (Houtkamp), and that I undervalue the virtues of weak versions of the latter (Salverda).

I do not agree with each of these criticisms, but I have learned from all of the essays. There is nothing as gratifying for an author than having his writings read carefully, pondered over open-mindedly, and discussed rigorously, especially when all this is done by scholars with competences he does not himself possess. ${ }^{2}$ This is how we can broaden together our knowledge, deepen our understanding, and improve our institutions and policies in a domain that is more important than ever for the smooth and fair funding of our societies and our world. I am most grateful to all the contributors to this volume, and especially to the latter's coordinator, László Marácz, for this wonderful opportunity.

2 See also the critical essays collected in P. Van Parijs \& al., The Linguistic Territoriality Principle. Right Violation or Parity of Esteem? Brussels: Re-Bel e-book $n^{\circ} 11,2011$, www.rethinkingbelgium. eu; and in H. De Schutter \& D. Robichaud (eds), Linguistic Justice; Van Parijs and his Critics, London: Routledge, 2016. 